Article

\title{
Propane Pre-Reforming into Methane-Rich Gas over Ni Catalyst: Experiment and Kinetics Elucidation via Genetic Algorithm
}

\author{
Sergey I. Uskov ${ }^{1,2}$, Dmitriy I. Potemkin ${ }^{1,2,3, * \mathbb{C}}$, Leniza V. Enikeeva ${ }^{2,4} \mathbb{D}^{\text {, Pavel V. Snytnikov }}{ }^{1,2}$, \\ Irek M. Gubaydullin ${ }^{5,6}$ and Vladimir A. Sobyanin ${ }^{1}$ \\ 1 Boreskov Institute of Catalysis, Pr. Lavrentieva 5, Novosibirsk 630090, Russia; serg5810@gmail.com (S.I.U.); \\ pvsnyt@catalysis.ru (P.V.S.); sobyanin@catalysis.ru (V.A.S.) \\ 2 Energy-Saving Catalytic Processes Laboratory, Novosibirsk State University, Pirogova St. 2, \\ Novosibirsk 630090, Russia; leniza.enikeeva@yandex.ru \\ 3 Department of Environmental Engineering, Novosibirsk State Technical University, Karl Marx Pr. 20, \\ Novosibirsk 630073, Russia \\ 4 Mathematical Department, Ufa State Petroleum Technological University, Kosmonavtov St. 1, \\ Ufa 450062, Russia \\ 5 Technological Department, Ufa State Petroleum Technological University, Kosmonavtov St. 1, \\ Ufa 450062, Russia; irekmars@mail.ru \\ 6 Institute of Petrochemistry and Catalysis of RAS, October Pr. 141, Ufa 450075, Russia \\ * Correspondence: potema@catalysis.ru; Tel.: +7-913-932-4620
}

Received: 21 May 2020; Accepted: 30 June 2020; Published: 2 July 2020

\begin{abstract}
Pre-reforming of propane was studied over an industrial nickel-chromium catalyst under pressures of 1 and 5 bar, at a low steam to carbon molar ratio of 1 , in the temperature range of $220-380{ }^{\circ} \mathrm{C}$ and at flow rates of 4000 and $12,000 \mathrm{~h}^{-1}$. It was shown that propane conversion proceeded more efficiently at low pressure $(1 \mathrm{~atm})$ and temperatures above $350{ }^{\circ} \mathrm{C}$. A genetic algorithm was applied to search for kinetic parameters better fitting experimental results in such a wide range of experimental conditions. Power law and Langmuir-Hinshelwood kinetics were considered. It was shown that only Langmuir-Hinshelwood type kinetics correctly described the experimental data and could be used to simulate the process of propane pre-reforming and predict propane conversion under the given reaction conditions. The significance of Langmuir-Hinshelwood kinetics increases under high pressure and temperatures below $350{ }^{\circ} \mathrm{C}$.
\end{abstract}

Keywords: liquefied petroleum gas; pre-reforming; propane; kinetics; nickel catalyst; genetic algorithm

\section{Introduction}

Despite the growing contribution of renewable energy sources, such as solar/wind energy or biomass, and respective technologies and devices for energy generation and storage, it is believed that for many decades, fossil resources (primarily oil and natural gas) will still form the basis of global energy consumption. An increase in the efficiency of using hydrocarbon raw materials while improving operational characteristics (an important factor for the final consumer) is associated with the use of fuel cells (FCs) and hydrogen storage technologies for the needs of distributed energy $[1,2]$. Therefore, fuel cells, which allow for converting the energy of chemical bonds into electrical energy with high efficiency even in compact and mobile systems, are one of the most dynamically developing energy sectors. 
At the moment, the infrastructure for supplying hydrogen and logistics are not well developed to meet mass consumption needs: there is a lack of hydrogen gas stations, and long-term storage of large quantities of hydrogen remains problematic. In this regard, most of the world research centers involved in the development of fuel cell based power plants show interest in the use of widely available traditional logistic fuels (gasoline, propane-butane, kerosene and diesel fuel). Besides, in comparison with other hydrogen storage technologies available today, hydrocarbon fuels contain the largest amount of hydrogen per unit volume [3]. Therefore, the use of liquid or easily liquefied hydrocarbon fuels with high energy density is relevant for fuel cells. However, such fuels cannot be directly oxidized in the anode space of the fuel cell, since they initiate the carbonization of the electrode and the failure of the fuel cell. In this case, the fuels are first converted to a hydrogen-containing gas and then oxidized in the fuel cell. The processes of steam conversion or steam reforming (SC), autothermal reforming (ATR) and partial oxidation (PO) are used to obtain synthesis gas from hydrocarbons. The most effective process is $\mathrm{SC}$, but it requires high operating temperatures, consumes a significant amount of heat to evaporate water and preheats steam and needs a water purification system. Therefore, SC can be implemented only for stationary power plants based on high-power fuel cells. PO of liquid hydrocarbon fuels has not yet been implemented due to thermodynamic limitations, an undesirable side process of carbon formation and high operating temperatures.

In order to solve the problem of partial oxidation of $\mathrm{C}_{2}-\mathrm{C}_{10}$ hydrocarbons, reach high performance and minimize the amount of water to be vaporized, it is proposed to combine the pre-reforming of hydrocarbons and the partial oxidation of the resulting methane-containing mixture into synthesis gas. The first stage is carried out at low molar ratios of $\mathrm{H}_{2} \mathrm{O} / \mathrm{C}=0.7-1.5$ and temperatures of $250-350{ }^{\circ} \mathrm{C}$. At these conditions, the main reaction products are methane, hydrogen and carbon dioxide. The second stage (PO) provides a high performance for the overall process of synthesis gas production.

Although catalytic steam conversion of hydrocarbons has been studied quite well, in the vast majority of works, the process was studied at temperatures of $450-700{ }^{\circ} \mathrm{C}$ and a molar ratio of $\mathrm{H}_{2} \mathrm{O} / \mathrm{C}$ $>2$ to obtain synthesis gas directly from hydrocarbons. SC of $\mathrm{C}_{2+}$-hydrocarbons at $\mathrm{H}_{2} \mathrm{O} / \mathrm{C}<1$ and temperatures below $350{ }^{\circ} \mathrm{C}$ are poorly studied. However, there is a limited number of works [4-7] showing the feasibility of such an approach to obtain methane-hydrogen mixtures.

Nickel-based catalysts are usually used in hydrocarbons steam reforming because of their high activity and low cost compared to platinum metals. Currently, nickel catalysts for methanation of carbon oxides, the pre-reforming of $\mathrm{C}_{2+}$-hydrocarbons and the steam conversion of natural gas to synthesis gas are available commercially. Natural gas steam reforming catalysts possess high mechanical strength, a Ni content of about $10-15 \mathrm{wt} . \%$ and can be used at temperatures of $700-900{ }^{\circ} \mathrm{C}$. As a result, the catalysts for natural gas steam conversion have a low nickel surface area and low catalytic activity at low temperatures. Conventional pre-reforming catalysts contain $15-30 \mathrm{wt} . \%$ of $\mathrm{Ni}$ and can be used at temperatures of $450-600{ }^{\circ} \mathrm{C}$. These catalysts were developed with particular attention to carbonization resistance [8] rather than catalytic activity. $\mathrm{CO} / \mathrm{CO}_{2}$ methanation catalysts have a high nickel content and dispersion but lack thermal stability and are usually operated at temperatures of $300-320^{\circ} \mathrm{C}$. Since the pre-reforming of hydrocarbons at such low steam to carbon molar ratios is carried out at about $250-350^{\circ} \mathrm{C}$ [5], the use of methanation catalysts seems to be the optimal choice.

There are a lack of data on the reaction kinetics for pre-reforming at such low temperatures and the steam to carbon molar ratio. Ethane steam conversion was studied in methane excess at molar ratios of $\mathrm{CH}_{4} / \mathrm{C}_{2} \mathrm{H}_{6} \approx 20$ and $\mathrm{H}_{2} \mathrm{O} / \mathrm{C}_{\mathrm{C} 2+}=0.6-6$ over a Ni-Cr catalyst at $300-360{ }^{\circ} \mathrm{C}, 1 \mathrm{~atm}$ pressure [9]. It was shown that ethane conversion rate could be described by a Langmuir-Hinshelwood type equation:

$$
\mathrm{W}_{\mathrm{C} 2 \mathrm{H} 6}=\mathrm{k} \cdot \mathrm{P}_{\mathrm{C} 2 \mathrm{H} 6} /\left(1+\mathrm{A} \cdot \mathrm{P}_{\mathrm{H} 2 \mathrm{O}} / \mathrm{P}_{\mathrm{H} 2}\right)
$$

where $\mathrm{k}$ and $\mathrm{A}$ are constants dependable of temperature; $\mathrm{P}_{\mathrm{C} 2 \mathrm{H} 6}, \mathrm{P}_{\mathrm{H} 2 \mathrm{O}}$ and $\mathrm{P}_{\mathrm{H} 2}$ are partial pressures of the components. The equation corresponds to a scheme with ethane adsorption being the rate-determining step. 
A two-stage macrokinetic scheme was suggested for the low-temperature steam conversion of methane-propane mixtures over Ni-based catalysts [10]. Conversion of the methane-pentane mixtures under 1 bar pressure was simulated using the scheme, which included irreversible reactions of the steam conversion of $\mathrm{C}_{2+}$-hydrocarbons, Equation (2), with the formation of $\mathrm{CO}_{2}$ and $\mathrm{H}_{2}$, followed by reversible $\mathrm{CO}_{2}$ methanation, Equation (3):

$$
\begin{gathered}
\mathrm{C}_{\mathrm{n}} \mathrm{H}_{2 \mathrm{n}+2}+2 \mathrm{nH}_{2} \mathrm{O} \rightarrow(3 \mathrm{n}+1) \mathrm{H}_{2}+\mathrm{nCO}_{2}(\mathrm{n}>1) \\
\mathrm{CO}_{2}+4 \mathrm{H}_{2} \rightleftarrows \mathrm{CH}_{4}+2 \mathrm{H}_{2} \mathrm{O} .
\end{gathered}
$$

Kinetic parameters were determined: $\mathrm{CO}_{2}$ methanation was shown to occur in a quasi-equilibrium mode at $\mathrm{T}>250{ }^{\circ} \mathrm{C}$. The apparent reaction order with respect to $\mathrm{C}_{3} \mathrm{H}_{8}$ was close to one. The effect of the $\mathrm{CH}_{4}, \mathrm{CO}_{2}, \mathrm{H}_{2}$ and $\mathrm{H}_{2} \mathrm{O}$ concentrations on the $\mathrm{C}_{3} \mathrm{H}_{8}$ conversion was insignificant. It should be noted that the kinetics are valid for $\mathrm{C}_{2+}$-hydrocarbons partial pressure much lower that 1 bar. Thus, kinetics for a wider pressure range are required.

The kinetic study of heterogenous catalytic reactions is generally a challenging task as mechanisms are typically multistep and the majority of experimental data are obtained in a plug-flow reactor in which the reaction conditions and reaction rates are different at all points of the reactor. The kinetic parameters are determined by solving an inverse problem of chemical kinetics.

The pre-reforming of the propane reaction is a complex chemical reaction, in other words, a multi-stage one, and for each stage of the reaction, it is necessary to find the kinetic parameters (activation energies and preexponential factors). Moreover, as will be shown later, we will look for additional reaction parameters when solving the inverse problem. Thus, an ill-posed optimization problem with high dimensionality is formulated. For these reasons, an efficient multidimensional optimization technique such as genetic algorithms (GAs) are, therefore, necessary. Genetic algorithms were designed for the accelerated search of a global minimum in various optimization problems [11-14]. It was successfully applied for the kinetics elucidation of [15-19].

In this work, the experiments on propane pre-reforming were carried out over an industrial nickel methanation catalyst NIAP-07-05, and a mathematical simulation was applied to describe the process. The effect of temperature and pressure was studied. The experiments data were fitted by the power law (PL) and Langmuir-Hinshelwood (LH) kinetics.

\section{Materials and Methods}

\subsection{Catalytic Experiments}

Propane pre-reforming was studied using an NIAP-07-05 industrial catalyst of the following composition (wt.\%): $42 \mathrm{NiO}, 12 \mathrm{Cr}_{2} \mathrm{O}_{3}, 46 \mathrm{Al}_{2} \mathrm{O}_{3}$ and 4 graphite. This catalyst was previously used in the studies on the low-temperature steam conversion of light hydrocarbons in methane excess $[5,10]$. The catalyst advantages are high activity and stability in propane reforming and resistance to carbon formation, which was confirmed by experiments during more than $40 \mathrm{~h}$.

The experiments were carried out in a fixed-bed U-shaped quartz reactor (i.e., $8 \mathrm{~mm}$, catalyst bed volume $1.7 \mathrm{~mL}$ ). Experimental conditions were as follows: $1-5$ bar pressure, $220-380{ }^{\circ} \mathrm{C}$, gas hourly space velocity (GHSV) is 4000 and $12,000 \mathrm{~h}^{-1}$. A measure of $2 \mathrm{~g}$ of the catalyst (fraction $0.5-1 \mathrm{~mm}$ ) was previously reduced at $420{ }^{\circ} \mathrm{C}$ in a flow of $10 \mathrm{~mL} / \mathrm{min} \mathrm{H}_{2}$ and $100 \mathrm{~mL} / \mathrm{min}$ Ar. The composition of the reaction mixture was 25 vol. $\% \mathrm{C}_{3} \mathrm{H}_{8}$ and 75 vol. $\% \mathrm{H}_{2} \mathrm{O}$, which corresponded to $\mathrm{H}_{2} \mathrm{O} / \mathrm{C}$ molar ratio of 1 .

The temperature of the catalyst was measured directly in the middle of the catalyst bed at the centerline point with the use of a K-type thermocouple. The GC analysis was applied to determine the composition of the gas phase before and after the reactor. Components were determined using a Chromos GC-1000 chromatograph equipped with two thermal conductivity detectors (TCD) and one flame ionization detector (FID) detector with a methanator. $\mathrm{CH}_{4}, \mathrm{CO}_{2}$ and $\mathrm{H}_{2}$ were registered as main reaction products. The concentration of carbon monoxide was negligible (below 0.1 vol.\%) 
and, therefore, $\mathrm{CO}$ was not taken into account when processing the results. The carbon imbalance in all the experiments did not exceed \pm 1 rel. \%. The obtained results were compared with equilibrium concentrations, calculated using the HSC Chemistry 7.1 software package (Outotec, Finland).

\subsection{Kinetic Modeling}

Based on the experimental dependencies, the inverse chemical kinetics task was solved to determine the reaction rate constants and activation energies. These parameters were obtained by solving the direct task numerous times by enumerating the rate constants of the stages (or a set of pre-exponents and activation energies). The model of an iso-thermal plug-flow rector was used for solving the direct problem. The task was to minimize the functional Equation (4) of the deviation of the experimental data from the calculated data:

$$
F=\sum_{i=1}^{M} \sum_{j=1}^{N}\left|x_{i j}^{c a l c}-x_{i j}^{e x p}\right| \rightarrow \min ,
$$

where $x_{\mathrm{ij}}^{\text {calc }}$ are the calculated values, $x_{\mathrm{ij}} \exp$ are the experimental data, $M$ is the number of experimental points (temperatures) and $N$ is the number of substances involved in the reaction.

When solving the direct task, the concentrations of the reaction components were calculated. The results were compared with experimental data, which mathematically meant minimizing the difference between the experimental and calculated data. A genetic algorithm was chosen as a method for solving the inverse task. The authors developed a program in the Matlab environment using the Optimization toolbox (see Supplementary Materials). Population sizes between 50 and 250 were used. As a rule, the higher the population size, the faster the algorithm converges to a solution, but this greatly affects the calculation time. The algorithm terminates when there is no further improvement in fitness function $F$ (see Equation (4)) after several hundred generations.

Four kinetics constants were optimized when solving the inverse task: $E_{\text {ref }}$ and $E_{\text {met }}(\mathrm{kJ} / \mathrm{mol})$, and $\mathrm{k}_{\mathrm{ref}}$ and $\mathrm{k}_{\mathrm{met}}$. These parameters were limited according to the concepts of the kinetics of low-temperature steam conversion of $\mathrm{C}_{2+}$-hydrocarbons in methane excess [8]: $90 \leq \mathrm{E}_{\text {ref }} \leq 150$; $30 \leq \mathrm{E}_{\text {met }} \leq 60 ; 10^{10} \leq \mathrm{k}_{\text {ref }} \leq 10^{13} ; 10^{4} \leq \mathrm{k}_{\text {met }} \leq 10^{7}$. Also, the apparent reaction order with respect to propane was varied within the range $-1<\mathrm{n}<1$ for PL kinetics. Constants $\mathrm{m}$ and B (see Equation (10)) were varied for LH kinetics.

\section{Results and Discussion}

Propane pre-reforming experiments were carried out at $220-380^{\circ} \mathrm{C}$. The main reaction products were methane, hydrogen and carbon dioxide, as well as residual propane. Figure $1 \mathrm{a}-\mathrm{d}$ shows the temperature dependences of the outlet concentrations of propane, methane, carbon dioxide and hydrogen during propane pre-reforming under pressures 1 bar and 5 bar. The flow rates (GHSV) for both pressures were 4000 and $12,000 \mathrm{~h}^{-1}$. It is seen that the conversion of propane proceeds more efficiently under 1 bar pressure. Complete propane conversion can be reached at temperatures above $350^{\circ} \mathrm{C}$.

It can be seen that at 1 bar pressure and a flow rate of $12,000 \mathrm{~h}^{-1}$, there is a maximum of hydrogen concentration at $290^{\circ} \mathrm{C}$, followed by a decrease to a minimum at $320^{\circ} \mathrm{C}$, and then a further increase. This can be explained that at low temperatures, hydrogen and $\mathrm{CO}_{2}$ were accumulating during the steam conversion reaction. With increasing temperature, hydrogen is consumed by the hydrogenolysis of propane. At high temperatures, the hydrogen concentration is determined by the equilibrium distribution of the products and increases according to the equilibrium of the $\mathrm{CO}_{2}$ methanation reaction. 

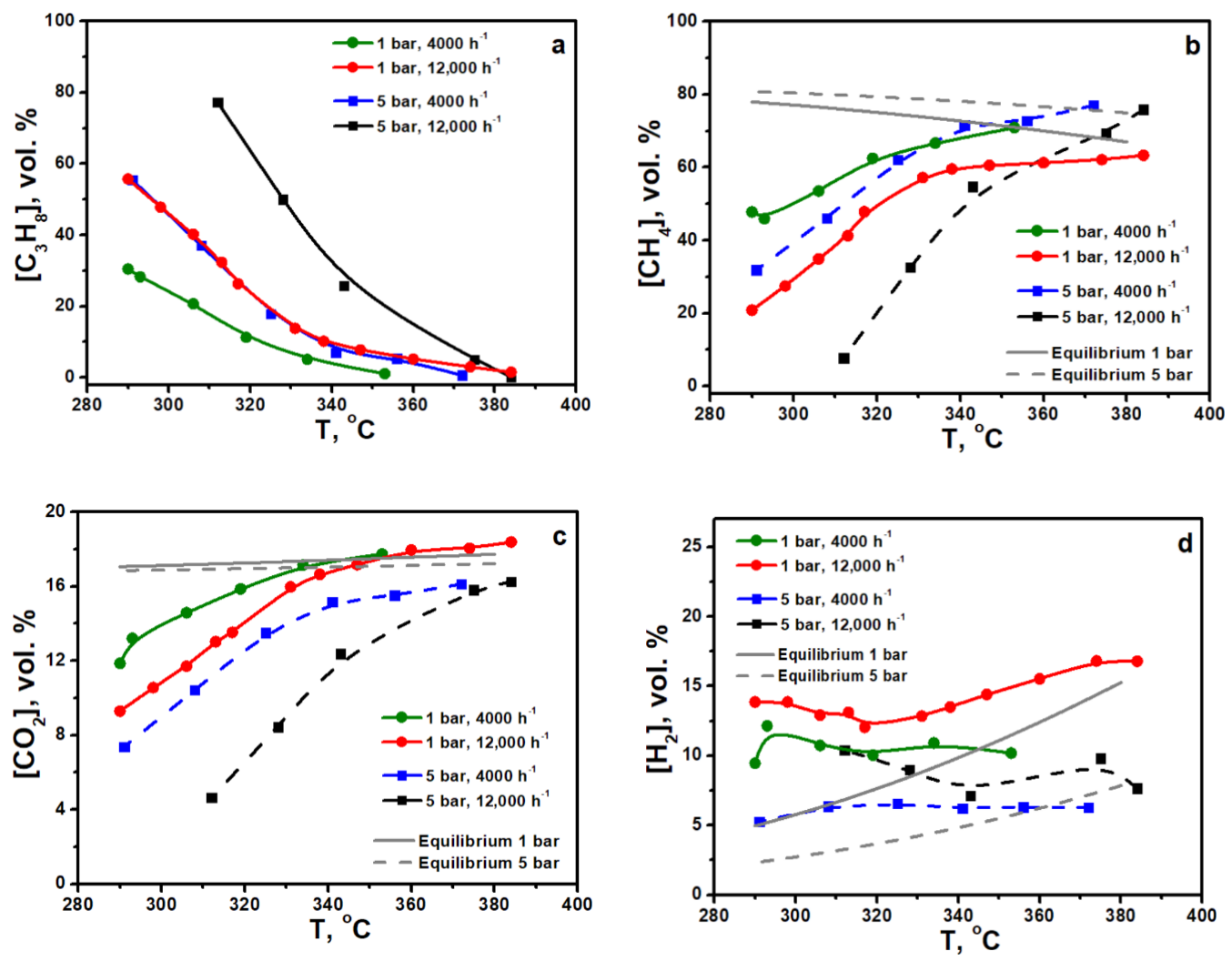

Figure 1. Temperature dependences of the outlet concentrations on a dry basis of propane (a), methane (b), carbon dioxide (c) and hydrogen (d) during propane pre-reforming. Experimental conditions: 220-380 ${ }^{\circ} \mathrm{C}$, GHSV 4000 and 12,000 $\mathrm{h}^{-1}, 1$ and 5 bar pressure and reaction mixture: 25 vol. $\% \mathrm{C}_{3} \mathrm{H}_{8}$, $75 \mathrm{vol} \% \mathrm{H}_{2} \mathrm{O}$. Concentrations of the gas components on the figure are given on the dry basis.

The inverse problem was then solved for the experiments on propane pre-reforming. The reaction scheme consisted of two reactions: steam conversion of propane and methanation of $\mathrm{CO}_{2}$.

$$
\begin{gathered}
\mathrm{C}_{3} \mathrm{H}_{8}+6 \mathrm{H}_{2} \mathrm{O} \rightarrow 10 \mathrm{H}_{2}+3 \mathrm{CO}_{2}, \\
\mathrm{CO}_{2}+4 \mathrm{H}_{2}=\mathrm{CH}_{4}+2 \mathrm{H}_{2} \mathrm{O} .
\end{gathered}
$$

Earlier, it was shown that this approach can be quite effective in the case of the low-temperature steam conversion of small concentrations of propane in methane excess [10]. In this work, we use the following form of the kinetic equations:

$$
\begin{gathered}
\mathrm{W}_{\text {ref }}=\mathrm{k}_{\text {ref }} \cdot \exp \left(-\frac{\mathrm{E}_{\text {ref }}}{\mathrm{RT}}\right) \cdot \mathrm{C}_{\mathrm{C} 3 \mathrm{H} 8^{\prime}}^{\mathrm{n}} \\
\mathrm{W}_{\text {met }}=\mathrm{k}_{\mathrm{met}} \cdot \exp \left(-\frac{\mathrm{E}_{\mathrm{met}}}{\mathrm{RT}}\right) \cdot \mathrm{C}_{\mathrm{H} 2} \cdot\left[1-\frac{\mathrm{P}_{\mathrm{CH} 4} \mathrm{P}_{\mathrm{H} 2 \mathrm{O}}^{2}}{\mathrm{~K}_{\mathrm{eq}} \mathrm{P}_{\mathrm{CO} 2} \mathrm{P}_{\mathrm{H} 2}^{4}}\right],
\end{gathered}
$$

where $W_{\text {ref }}$ and $W_{\text {met }}$ are the reaction rates $\left(\mathrm{mol} \cdot \mathrm{m}^{-3} \cdot \mathrm{sec}^{-1}\right) ; E_{\text {ref }}$ and $E_{\text {met }}$ are the observed activation energies $(\mathrm{J} / \mathrm{mol}) ; \mathrm{k}_{\text {ref }}$ and $\mathrm{k}_{\text {met }}$ are pre-exponential factors $\left(\left(\mathrm{mol} \cdot \mathrm{m}^{3}\right)^{\mathrm{n}-1} \cdot \mathrm{sec}^{-1} \mathrm{and} \mathrm{sec}^{-1}\right)$. The indices ref and met refer to the pre-reforming and methanation reactions, respectively. $\mathrm{C}_{\mathrm{C} 3 \mathrm{H} 8}$ and $\mathrm{C}_{\mathrm{H} 2}$ are concentrations of propane and hydrogen $\left(\mathrm{mol} / \mathrm{m}^{3}\right) ; \mathrm{n}$ is effective reaction order with respect to propane, which ranged from -2 to $2 ; \mathrm{K}_{\mathrm{eq}}$ is the equilibrium constant for $\mathrm{CO}_{2}$ methanation reaction and $\mathrm{P}_{\mathrm{CH} 4}$, $\mathrm{P}_{\mathrm{H} 2 \mathrm{O}}, \mathrm{P}_{\mathrm{CO} 2}, \mathrm{P}_{\mathrm{H} 2}$ are partial pressures of the corresponding substances (bar). 
As a result of solving the inverse task, the values of $\mathrm{E}_{\mathrm{ref}}, \mathrm{E}_{\mathrm{met}}, \mathrm{k}_{\text {ref }}, \mathrm{k}_{\text {met }}$ and $\mathrm{n}$ were optimized. The obtained values are listed in Table 1.

Table 1. The values of $\mathrm{E}_{\text {ref }}, \mathrm{E}_{\text {met }}, \mathrm{k}_{\text {ref }}, \mathrm{k}_{\text {met }}$ and $\mathrm{n}$ obtained by solving the inverse task.

\begin{tabular}{ccccc}
\hline $\mathbf{E}_{\text {ref }}, \mathbf{k J} / \mathbf{m o l}$ & $\mathbf{E}_{\mathbf{m e t}}, \mathbf{k J} / \mathbf{m o l}$ & $\mathbf{k}_{\text {ref }}\left(\mathbf{m o l} \cdot \mathbf{m}^{\mathbf{- 3}}\right)^{\mathbf{n}-\mathbf{1}} \cdot \mathbf{s e c}^{\mathbf{- 1}}$ & $\mathbf{k}_{\text {met }}, \mathbf{s e c}^{\mathbf{- 1}}$ & $\mathbf{n}$ \\
\hline 107.5 & 46.7 & $4.0 \cdot 10^{10}$ & $3.2 \cdot 10^{5}$ & 0.15 \\
\hline
\end{tabular}

These parameters were substituted into Equations (7) and (8). Next, within the framework of the proposed reaction scheme and the model of a quasi-homogeneous isothermal plug flow reactor, the system of the material balance equations was solved to calculate the temperature dependences of the reaction product concentrations. The system of differential equations is written in the following form:

$$
\mathrm{G} \frac{\mathrm{dy}}{\mathrm{dz}}=v_{\mathrm{i}} \mathrm{W}_{\mathrm{ref}} \rho_{\mathrm{i}} \text {. }
$$

Here, $\mathrm{G}$ is the mass flow of the gas mixture $\left(\mathrm{kg} \cdot \mathrm{m}^{-2} \cdot \mathrm{sec}^{-1}\right) ; \mathrm{y}_{\mathrm{i}}$ is the mass fraction of the $\mathrm{i}$-th component, $\mathrm{i}=\left\{\mathrm{C}_{3} \mathrm{H}_{8}, \mathrm{CH}_{4}, \mathrm{H}_{2} \mathrm{O}, \mathrm{H}_{2}, \mathrm{CO}_{2}\right\} ; \mathrm{z}$ is the coordinate along the catalyst bed $(0 \leq \mathrm{z} \leq 0.030 \mathrm{~m})$; $v_{\mathrm{i}}$ are stoichiometric coefficients for steam reforming reactions; $\mathrm{W}_{\text {ref }}$ is the steam conversion rate of propane $\left(\mathrm{mol} \cdot \mathrm{m}^{-3} \cdot \mathrm{s}^{-1}\right)$ and $\rho_{\mathrm{i}}$ is the density of the i-th component $\left(\mathrm{kg} \cdot \mathrm{m}^{-3}\right)$. The boundary conditions were expressed as: $\mathrm{y}_{\mathrm{i}}=\mathrm{y}_{\mathrm{i} 0}$ at $\mathrm{z}=0$.

The calculation results for the experiments under 1 and 5 bar and flow rates of 4000 and 12,000 $\mathrm{h}^{-1}$ are shown in Figure $2 \mathrm{a}-\mathrm{d}$. It is seen that power low type kinetics correctly describes the experimental data at low temperatures for both pressures, while for high pressure, it predicts the reaching the equilibrium too fast. Note that the effective reaction order with respect to propane $(n=0.15)$ in the case of the pre-reforming of pure propane is less than or close to zero, in contrast to the conversion of diluted propane-methane mixtures [10]. The reason for this is the high coverage of the catalyst surface with propane molecules $\left(\theta_{\mathrm{C} 3 \mathrm{H} 8}\right)$, which, according to the Langmuir-Hinshelwood model, reduces the effective reaction order.

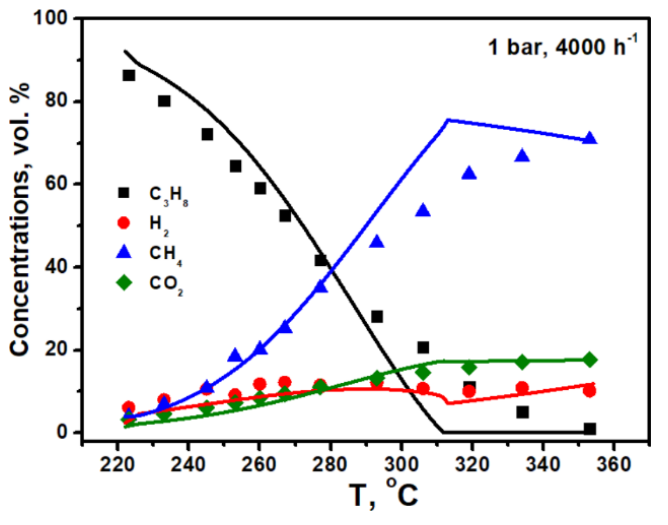

(a)

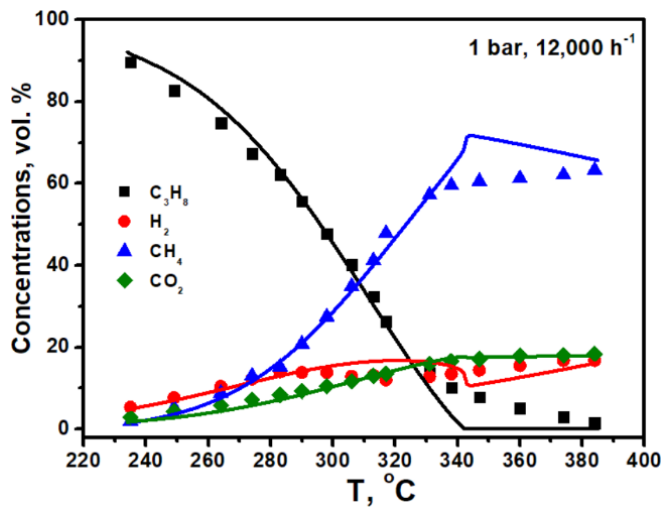

(b)

Figure 2. Cont. 


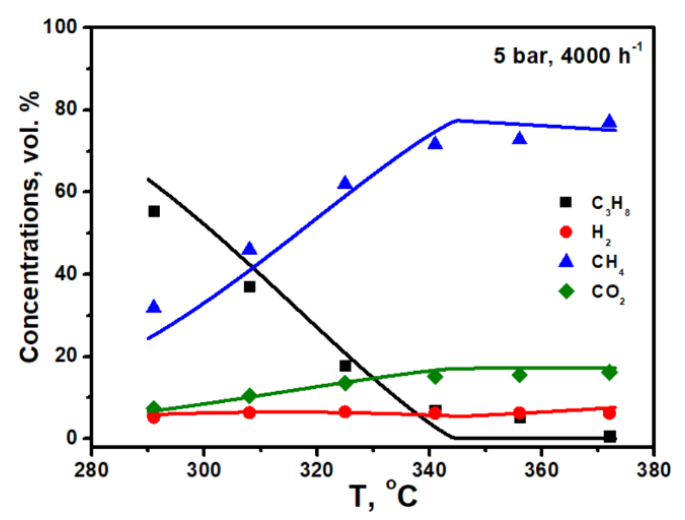

(c)

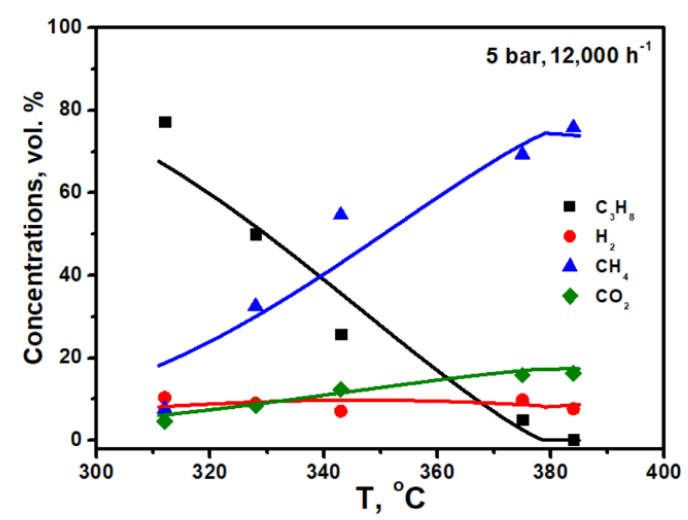

(d)

Figure 2. Temperature dependences of the outlet concentrations of propane, methane, $\mathrm{CO}_{2}$ and hydrogen in propane pre-reforming. Points are the experiment, and lines are the modeling. Experimental conditions: 25 vol. $\% \mathrm{C}_{3} \mathrm{H}_{8}, 75 \% \mathrm{H}_{2} \mathrm{O}$ and pressure 1 bar. The solution of the inverse problem is power law dependence with a propane effective reaction order of 0.15 . Concentrations of the gas components on the figure are given on the dry basis. Figure 2a shows the results for the experiments under 1 bar and $4000 \mathrm{~h}^{-1}$, Figure $2 \mathrm{~b}-1$ bar and $12,000 \mathrm{~h}^{-1}$, Figure $2 \mathrm{c}-5$ bar and $4000 \mathrm{~h}^{-1}$, Figure $2 \mathrm{~d}-5 \mathrm{bar}$ and $12,000 \mathrm{~h}^{-1}$.

Aside from the power law dependence, attempts were made to find the solution of the inverse task in the form of the Langmuir-Hinshelwood (LH) model:

$$
\text { Wref }=\frac{k_{\text {ref }} \cdot \exp \left(-\frac{E_{\text {ref }}}{R T}\right) \cdot C_{\mathrm{C} 3 \mathrm{H} 8}}{\left(1+B \cdot C_{\mathrm{C} 3 \mathrm{H} 8}\right)^{m}}
$$

The value of $\mathrm{B}$ constant varied from 0 to 5 , and the value of $\mathrm{m}$ varied from 0 to 2 . When solving the inverse problem, the values of $\mathrm{E}_{\text {ref }}, \mathrm{E}_{\text {met }}, \mathrm{k}_{\text {ref }}$ and $\mathrm{k}_{\text {met }}$ also varied (the upper and lower restrictions were the same as for the power law model). The results are shown in Table 2.

Table 2. The values of $\mathrm{B}, \mathrm{m}, \mathrm{E}_{\text {ref }}, \mathrm{E}_{\text {met }}, \mathrm{k}_{\mathrm{ref}}$ and $\mathrm{k}_{\text {met }}$ optimized in the framework of the Langmuir-Hinshelwood model.

\begin{tabular}{cccccc}
\hline $\mathbf{E}_{\text {ref }}, \mathbf{~} \mathbf{~ J} / \mathbf{m o l}$ & $\mathbf{E}_{\text {met }}, \mathbf{k J} / \mathbf{m o l}$ & $\mathbf{k}_{\text {ref }},\left(\mathbf{m o l} \cdot \mathbf{m}^{\mathbf{3}}\right)^{\mathbf{n}-\mathbf{1}} \cdot \mathbf{s e c}^{-\mathbf{1}}$ & $\mathbf{k}_{\text {met }}, \mathbf{s e c}^{-\mathbf{1}}$ & $\mathbf{m}$ & $\mathbf{B}$ \\
\hline 105.1 & 44.2 & $1.3 \cdot 10^{10}$ & $1.6 \cdot 10^{5}$ & 1.067 & 0.204 \\
\hline
\end{tabular}

These values were used to solve the direct task. Figure 3a-d shows the results of the calculations for experiments on propane pre-reforming under 1 bar and 5 bar.

It is seen that the model based on the Langmuir-Hinshelwood mechanism correctly describes the experimental data. It is seen that apparent activation energies for both fits are quite close. The main difference is in the nature of the dependence of the rate of conversion of propane on its concentration. 


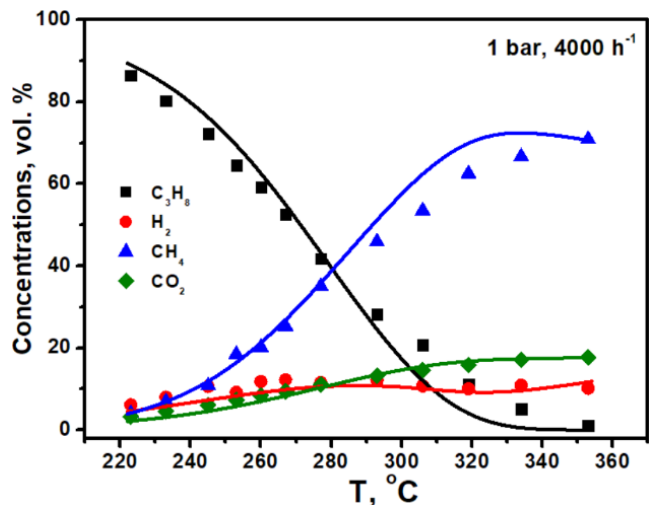

(a)

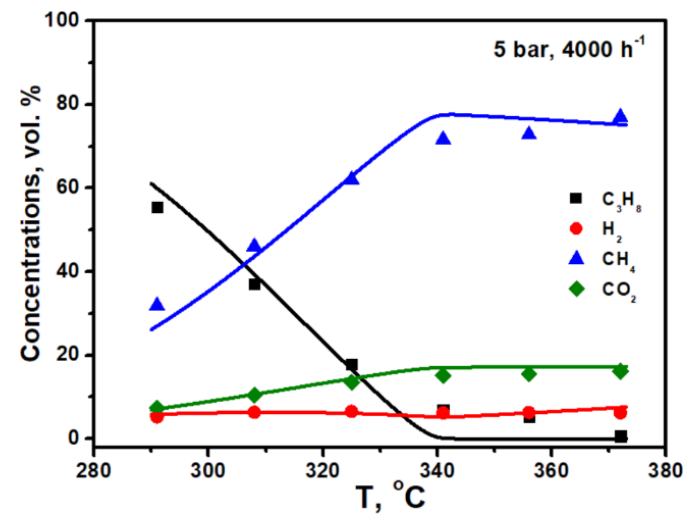

(c)

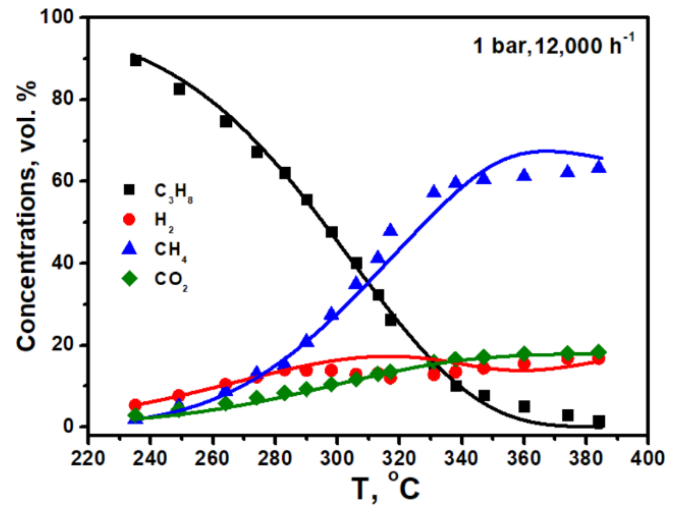

(b)

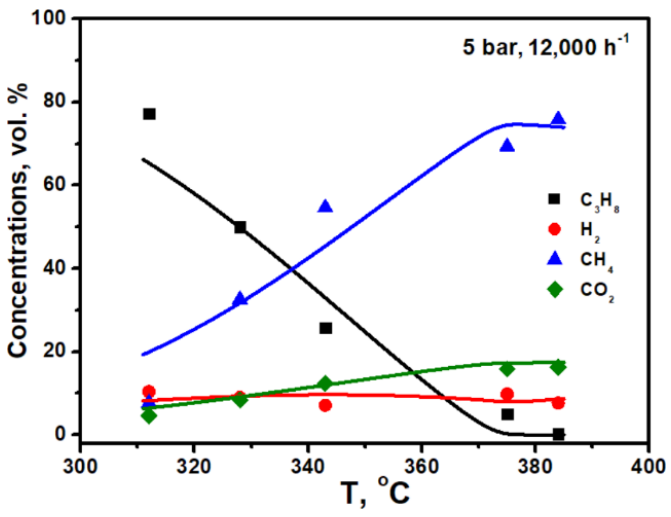

(d)

Figure 3. Temperature dependences of the outlet concentrations of propane, methane, $\mathrm{CO}_{2}$ and hydrogen in propane pre-reforming. Points are the experiment, and lines are the modeling. Experimental conditions: 25 vol. $\% \mathrm{C}_{3} \mathrm{H}_{8}, 75 \% \mathrm{H}_{2} \mathrm{O}$ and pressure 1 bar. The solution of the inverse problem is according to the Langmuir-Hinshelwood (LH) model. Concentrations of the gas components on the figure are given on the dry basis. Figure 3a shows the results for the experiments under 1 bar and $4000 \mathrm{~h}^{-1}$, Figure $3 \mathrm{~b}-1$ bar and $12,000 \mathrm{~h}^{-1}$, Figure $3 \mathrm{c}-5$ bar and $4000 \mathrm{~h}^{-1}$, Figure $3 \mathrm{~d}-5 \mathrm{bar}$ and $12,000 \mathrm{~h}^{-1}$.

Figure 4 shows the temperature dependence of the denominator of Equation (10), which shows how the value of $\left[1+\mathrm{B} \cdot \mathrm{C}_{\mathrm{C} 3 \mathrm{H} 8}\right]^{\mathrm{m}}$ varies with temperature and pressure (with parameters $\mathrm{B}$ and $\mathrm{m}$ selected). It is seen that the denominator varies within the range of 1-3 under the conditions studied, and decreases with pressure decrease and temperature increase. The results obtained explain the inconsistency of the power law kinetics: at a low temperature, the apparent reaction order with respect to propane is close to zero, providing good agreement of experiment and fitting; however, with temperature increase, the apparent propane reaction order becomes closer to one, but power law kinetics cannot reflect this, therefore making it inappropriate. 


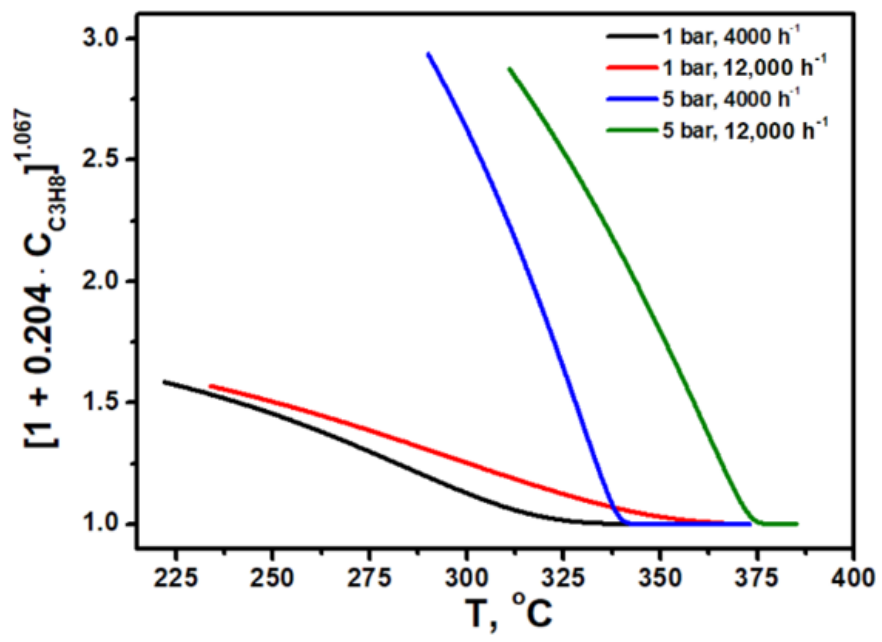

Figure 4. Temperature dependence of the denominator of the Langmuir-Hinshelwood model for the experiments on propane pre-reforming under 1 bar and 5 bar and at flow rates of 4000 and $12,000 \mathrm{~h}^{-1}$.

\section{Conclusions}

The temperature dependences of the concentrations of the products for propane pre-reforming were obtained under 1 and 5 bar, $\mathrm{H}_{2} \mathrm{O} / \mathrm{C}=1$ ratio, in the temperature range of $220-380{ }^{\circ} \mathrm{C}$ and at flow rates of 4000 and $12,000 \mathrm{~h}^{-1}$. It was shown that propane conversion over the industrial NIAP-07-05 catalyst $\left(42 \% \mathrm{NiO}, 12 \% \mathrm{Cr}_{2} \mathrm{O}_{3}, 46 \% \mathrm{Al}_{2} \mathrm{O}_{3}, 4 \% \mathrm{C}\right.$ ) proceeds more efficiently at low pressure (1 atm) and temperatures above $350{ }^{\circ} \mathrm{C}$. Mathematical modeling of the experimental dependencies was carried out according to two models: a power law model and the Langmuir-Hinshelwood mechanism. A genetic algorithm was used to obtain the best fit within the models used. It was shown that the LH model correctly describes the experimental data and can be used to simulate the process of propane pre-reforming and predict propane conversion under given reaction conditions. The significance of the LH model increases under high pressure and temperatures below $350^{\circ} \mathrm{C}$.

Supplementary Materials: The following are available online at http://www.mdpi.com/1996-1073/13/13/3393/s1, Supplementary materials for Propane Pre-Reforming into Methane-Rich Gas over Ni Catalyst: Experiment and Kinetics Elucidation via Genetic Algorithm.

Author Contributions: Conceptualization, D.I.P.; methodology, P.V.S.; software, L.V.E.; validation, I.M.G.; formal analysis, D.I.P.; investigation, D.I.P.; resources, D.I.P.; data curation, S.I.U.; writing-original draft preparation, D.I.P., S.I.U. and L.V.E.; supervision, V.A.S. All authors have read and agreed to the published version of the manuscript.

Funding: In the part of experimental study the work is supported by the RFBR project 19-33-60008 "Perspectiva" (D.I.P.). In the part of mathematical modelling the work is supported by the RFBR project 19-37-60014 "Perspectiva" (L.V.E.). S.I.U. appreciates support by the Ministry of Science and Higher Education of the Russian Federation (Project AAAA-A17-117041710088-0).

Conflicts of Interest: The authors declare no conflict of interest.

\section{References}

1. Ren, J.; Musyoka, N.M.; Langmi, H.W.; Mathe, M.; Liao, S. Current research trends and perspectives on materials-based hydrogen storage solutions: A critical review. Int. J. Hydrog. Energy 2017, 42, 289-311. [CrossRef]

2. Zhang, F.; Zhao, P.; Niu, M.; Maddy, J. The survey of key technologies in hydrogen energy storage. Int. J. Hydrog. Energy 2016, 41, 14535-14552. [CrossRef]

3. Shekhawat, D.; Berry, D.A.; Spivey, J.J. Introduction to Fuel Processing. In Fuel Cells: Technologies for Fuel Processing; Elsevier: Amsterdam, The Netherlands, 2011; pp. 1-9. [CrossRef]

4. Christensen, T.S. Adiabatic prereforming of hydrocarbons-an important step in syngas production. Appl. Catal. A Gen. 1996, 138, 285-309. [CrossRef] 
5. Zyryanova, M.M.; Snytnikov, P.V.; Amosov, Y.I.; Belyaev, V.D.; Kireenkov, V.V.; Kuzin, N.A.; Vernikovskaya, M.V.; Kirillov, V.A.; Sobyanin, V.A. Upgrading of associated petroleum gas into methane-rich gas for power plant feeding applications. Technological and economic benefits. Fuel 2013, 108, $2822-2891$. [CrossRef]

6. Rostrup-Nielsen, J.R.; Christiansen, L.J. Concepts in Syngas Manufacture; Imperial College Press: London UK, 2011; p. 379.

7. Rostrup-Nielsen, J.R. Catalytic Steam Reforming; Springer: Berlin, Germany, 1984; p. 119.

8. Rostrup-Nielsen, J.R.; Christensen, T.; Dybkjaer, I. Steam reforming of liquid hydrocarbons. Recent. Adv. Basic Appl. Asp. Ind. Catal. 1998, 113, 81-95.

9. Meshenko, N.T.; Veselov, V.V.; Shub, F.S.; Temkin, M.I. Kinetics of the low-temperature steam reforming of ethane on a nickel-chromium catalyst. Kinet. Catal. 1977, 18, 962-967.

10. Uskov, S.I.; Potemkin, D.I.; Shigarov, A.B.; Snytnikov, P.V.; Kirillov, V.A.; Sobyanin, V.A. Low-temperature steam conversion of flare gases for various applications. Chem. Eng. J. 2019, 368, 5335-5340. [CrossRef]

11. Bhoskar, T.; Kulkarni, N.K.; Patekar, S.; Bhoskar, T.; Kulkarni, O.; Kakandikar, G.M.; Nandedkar, V.M. Genetic Algorithm and its Applications to Mechanical Engineering: A Review. Mater. Today Proc. 2015, 2, 1624-2630. [CrossRef]

12. Wiśniewski, J. Optimal Design of Reinforcing Fibres in Multilayer Composites using Genetic Algorithms. Fibres Text. East. Eur. 2004, 12, 90-543.

13. Lam RatnaRaju, T.K. Design Optimization of Perforated Plate Heat Exchangers using Genetic Algorithm. Adv. Mater. Manuf. Charact. 2013, 3, 89-93. [CrossRef]

14. Chakraborti, N.; Kumar, R.; Jain, D. A study of the continuous casting mold using a pareto-converging genetic algorithm. Appl. Math. Model. 2001, 25, 2872-2897. [CrossRef]

15. Elliott, L.; Ingham, D.B.; Kyne, A.G.; Mera, N.S.; Pourkashanian, M.; Wilson, C.W. Genetic algorithms for optimisation of chemical kinetics reaction mechanisms. Prog. Energy Combust. Sci. 2004, 30, 297-328. [CrossRef]

16. Wolf, D.; Moros, R. Estimating rate constants of heterogeneous catalytic reactions without supposition of rate determining surface steps-An application of a genetic algorithm. Chem. Eng. Sci. 1997, 52, 1189-1199. [CrossRef]

17. Garcia, S. Experimental Design Optimization and Thermophysical Parameter Estimation of Composite Materials Using Genetic Algorithms. Ph.D. Thesis, Virginia Polytechnic Institute (and Universite de Nantes), Nantes, France, 1999.

18. Lautenberger, C.; Rein, G.; Fernandez-Pello, C. The application of a genetic algorithm to estimate material properties for fire modeling from bench-scale fire test data. Fire Safe. J. 2006, 41, 204-214. [CrossRef]

19. Rein, G.; Lautenberger, C.; Fernandez-Pello, A.C.; Torero, J.L.; Urban, D.L. Application of genetic algorithms and thermogravimetry to determine the kinetics of polyurethane foam in smoldering combustion. Combust. Flame 2006, 146, 95-108. [CrossRef]

(C) 2020 by the authors. Licensee MDPI, Basel, Switzerland. This article is an open access article distributed under the terms and conditions of the Creative Commons Attribution (CC BY) license (http://creativecommons.org/licenses/by/4.0/). 